\title{
Covering young 'Reed' avocado trees with shading nets during winter alleviates cold stress and promotes vegetative growth
}

\author{
S. Chernoivanov ${ }^{1}$, I. Neuberger ${ }^{1}$, S. Levy ${ }^{1}$, N. Szenes ${ }^{2}$ and L. Rubinovich ${ }^{1}$ \\ ${ }^{1}$ Northern R\&D, MIGAL - Galilee Research Institute, Kiryat Shmona, Israel \\ ${ }^{2}$ Agricultural Extension Service, Israel Ministry of Agriculture \& Rural Development, Beit Dagan, Israel
}

\begin{abstract}
Summary
Avocado is a commercially important sub-tropical fruit crop. Despite its popularity, most cultivars are susceptible to cold stress, that may result in yield losses and limits avocado geographic expansion. As shading nets are used to protect crops from environmental hazards, the objective of this study was to evaluate the effect of covering young 'Reed' avocado trees with shading nets during winter. Silver $50 \%$ and $70 \%$ nets were placed over young avocado trees during three consecutive winters while uncovered trees served as control. Measurements show that photosynthetically active radiation (PAR) in the control plots was significantly higher compared to both nets. Minimum air temperature under the shading nets was similar to that of the control, but maximum air temperature was generally lower. Mid-winter ratio of variable to maximum fluorescence (Fv/Fm) rates were lowest in the control trees and highest in trees covered with Silver $\mathbf{7 0 \%}$ net. Moreover, leaf chlorophyll content was generally higher in the covered trees, especially under Silver $\mathbf{7 0 \%}$. Furthermore, flowering intensity in trees covered with Silver $\mathbf{7 0 \%}$ was significantly lower than in the control trees. Finally, tree trunk diameter was lowest in the control trees and higher in trees covered with both nets, especially Silver $\mathbf{7 0 \%}$. In summary, the effect of the shading nets may be attributed to mitigation of chilling stress via a reduction in irradiation levels during winter. In conclusion, shading nets may be considered as a possible solution to mitigate cold stress in commercial orchards, reducing growers' losses and enabling geographic distribution and expansion of avocado orchards to colder areas.
\end{abstract}

Keywords

chilling, chlorophyll content, flowering, Persea

americana, photoselective nets, sub-tropical

\section{Introduction}

Avocado (Persea americana) is a commercially important sub-tropical fruit crop in Israel, as well as in many other countries around the world (Alcaraz et al., 2013). While the 'Hass' cultivar dominates world production, 'Reed' is an important cultivar in Israel, comprising close to $10 \%$ of Israeli avocado orchards $(\sim 1,000 \mathrm{ha})$, with an annual average yield of 15 ton ha-1 (Israeli Extension Services). Since the avocado originates from tropical and sub-tropical regions, some cultivars are considered to be susceptible to cold climatic events depending on their genetic background (Schaffer et

\section{Significance of this study}

What is already known on this subject?

- As climate change is becoming more intense, extreme cold events are becoming more frequent. Shading nets are commonly used to protect agricultural crops from harsh environmental hazards.

\section{What are the new findings?}

- In this study, it was found that covering young 'Reed' avocado trees with different shading nets during winter had a positive effect on the physiological parameters and vegetative growth.

What is the expected impact on horticulture?

- Shading nets may be considered as a possible solution to mitigate cold stress in commercial avocado orchards, as well as other commercially important tropical and sub-tropical fruit crops.

al., 2013). While some cultivars such as 'Hass' are considered to be cold-susceptible, others such as 'Ettinger' are considered to be cold-hardy and may sustain freezing temperatures up to $-5^{\circ} \mathrm{C}$, without apparent considerable damage (Weil et al., 2019). 'Reed,' a Guatemalan cultivar, is considered to be intermediate cold-tolerant (Silva and Ledesma, 2014).

In recent years, as world demand for avocado is on the rise (Migliore et al., 2017), areas in northern Israel suited for planting new sub-tropical orchards are becoming scarce. Still, growers are taking calculated risks and expanding avocado orchards into areas with high risk for extreme cold events. Moreover, as climate change is becoming more intense, extreme cold events are becoming more frequent, even in areas in which these events were once scarce (Zhang et al., 2012). Therefore, there is a real need to develop solutions to mitigate cold damage in mature and young avocado orchards.

Extreme cold events where temperatures drop below $0^{\circ} \mathrm{C}$ are referred to as frosts (De Melo-Abreu et al., 2016). Milder cold events where the minimum temperature decreases close to but higher than $0^{\circ} \mathrm{C}$ are referred to as chilling events (Jouyban et al., 2013). Generally in plants, freezing stress damage results from the formation of ice crystals within plant tissues, while chilling stress results from temperatures low enough to cause injury to plant tissues without ice formation (Hasanuzzaman et al., 2013). In avocado, frost damage may result in mild to severe noticeable damage to fruits, leaves, flowers and flower buds, depending on the duration and severity of the frost event (Joshi et al., 2019; Silva and Ledesma, 2014). However, damage to avocado trees following milder 
cold events, namely chill, is much less described, since plant tissues show almost no apparent damage. A previous study showed that ratio of variable to maximum fluorescence (Fv/ Fm) rates were lower for cold-stressed avocado tree leaves than for leaves of non-stressed trees, indicating that chill-induced photoinhibition of leaves had occurred during winter (Whiley et al., 1999).

In past years, numerous means were examined for their efficiency to mitigate extreme cold damage in fruit orchards. For example, the use of over-the-canopy water sprinklers and wind machines was evaluated in various crops including avocado (Bar-Noy et al., 2019; Ghaemi et al., 2009; Ribeiro et al., 2006). Shading nets are commonly used to protect agricultural crops from harsh environmental hazards such as hail, wind and excess sunlight (Manja and Aoun, 2019; Shahak et al., 2004, 2008), but little is known about their capability to reduce extreme cold damage. For example, a $50 \%$ aluminized shading screen was found to be the most effective method for reducing frost damage in peppers (Teitel et al., 1996). In another study, frost damage in banana plants under an Aluminet 50\% net was significantly less severe than in the control plants, which were covered with a crystal $10 \%$ net (Zait et al., 2020). Still, as there was no apparent need for developing methods to protect against chill events in avocado orchards, none of the above measures was evaluated for their chilling stress mitigation efficiency, especially in this crop.

Since young avocado plants are considered to be more susceptible to cold stress compared to adult trees, a competent protection technique should be implemented in the orchards (Zaro et al., 2019). The hypothesis of this study is that shading nets may alleviate cold damage in avocado orchards. Therefore, the main objective of the present study was to evaluate the effect of covering young 'Reed' avocado trees with different shading nets during winter. Since low bee activity and pollination services in trees grown under shade netting are serious causes of concern (Mditshwa et al., 2019), we chose to cover the trees only during winter when cold events are bound to happen.

\section{Materials and methods}

\section{Experimental site}

The experiments were conducted during 2017-2020 in a 0.3-ha commercial 'Reed' avocado orchard located in Ma'ayan Baruch in northwest Israel $\left(33^{\circ} 13^{\prime} \mathrm{N}\right.$; $35^{\circ} 37^{\prime} \mathrm{E}, 114-117 \mathrm{~m}$ a.s.l.). The trees were planted in April 2017 with 5 m spacing between rows and $3 \mathrm{~m}$ between trees. The rows were oriented north/south. Chilling temperatures occurred in the experimental orchard mainly from December to mid-February.

\section{Shading nets and experimental design}

From early November through mid-March of 2018, 2019 and 2020 Silver 50\% and Silver 70\% shading nets (Ginegar Plastic Products Ltd., Israel) were placed over the trees. In the winters of 2017-2018 and 2018-2019, the shading nets were supported by a metal construction built over the trees (Supplemental Figure S1). In the winter of 2019-2020, as the trees grew big enough, the shading nets were supported by the tree canopies. Trees from the control plot were not covered with shading nets (control trees). The experimental plots were completely randomized, 3-4 repeats for each treatment (control/shading nets). Each replicate contained five trees, and measurements were taken only from the three middle trees.

\section{Temperature and light measurements}

Field air temperature data were collected by miniature, waterproof single-channel Hobo temperature data loggers (catalog no. UA-001-64; Onset Corp., Bourne, MA, U.S.A.) placed $1.5 \mathrm{~m}$ above the ground on the western side of the trees, shaded from direct radiation by the canopy. Air temperature was measured continuously at 10-min intervals from early December until mid-March each year. Three temperature data loggers were placed for each treatment. Photosynthetically active radiation (PAR) was measured using Field Scout quantum meter (\#3415F, Spectrum Technologies, Inc., IL, U.S.A.). At least ten measurements were performed for each replicate $(n=4)$ of the different nets and control. Spectra of the total solar light under the different shading nets and the control (sunlight) were measured at noon in November 2020 using a field spectrometer (SS-110 VIS range spectroradiometer, Apogee Electronics Corp., CA, U.S.A.). Prior to the measurements, dark balance was performed with the light-sealed cap supplied with the sensor. At least five different measurements were performed for each of the different treatments.

\section{Flowering intensity estimation, tree trunk diameter and chlorophyll measurements}

Flowering intensity was assessed as described in BarNoy et al., and Ziv et al., (Bar-Noy et al., 2019; Ziv et al., 2014) during the bloom peak in early May 2019 and May 2020, with a blind test in which two surveyors independently scored each tree on a scale of $0-5$, with 0 representing no apparent flowering and 5 maximum flowering intensity. For trunk diameter measurements, the trunks were marked 10-15 $\mathrm{cm}$ above the ground, and their diameter was measured at the same height by a Vernier caliper in two-months intervals. Leaf chlorophyll concentration index (CCI) was measured using a chlorophyll meter (Apogee MC-100, Apogee Instruments, Logan, UT, U.S.A.). Measurements were taken from at least three different trees for each replicate, three leaves per tree.

\section{Chlorophyll $a$ fluorescence analysis}

After dark adaptation for at least $20 \mathrm{~min}$, chlorophyll $a$ fluorescence parameter was recorded under darkness with a FluorPen FP100 portable fluorometer (Photon Systems Instruments, Drasov, Czech Republic), and the ratio of variable to maximum fluorescence (Fv/Fm) was calculated (Baker, 2008; Kramer et al., 2004; Schreiber et al., 1986). Measurements were taken from at least three different trees for each replicate, three leaves per tree.

\section{Statistical analysis}

All results were subjected either to Tukey-HSD test using JMP software, v. 11.0.0 (SAS Institute, Cary, NC, U.S.A.).

\section{Results}

The location of the experimental site was chosen due to its high cold-risk quality. The trees were covered during winter with the different shading nets to investigate their effect.

\section{Effect of shading nets on PAR, solar spectrum and air temperature}

Photosynthetically active radiation (PAR) was significantly higher in the control plots compared to both net covered plots (Figure 1a). PAR in plots covered with the Silver $50 \%$ net was significantly higher compared to plots covered with the Silver $70 \%$ net. PAR in plots covered with the Silver 
$50 \%$ and Silver $70 \%$ nets was $39 \%$ and $18.7 \%$ of the control, respectively. Thus, the actual shading rate of the different shading nets was slightly higher than expected. Solar spectrum measurements show similar radiation pattern between the control and the two nets, but with differences in the radiation rates (Figure 1b). In all of the wavelengths, both nets transmitted less light than the control and Silver 70\% nets absorbed more light than the Silver 50\% net.

During the three winters of the experiment, the minimum air temperature in the orchard did not fall below $0^{\circ} \mathrm{C}$. In the winters of 2017-2018, 2018-2019 and 2019-2020, minimum air temperatures reached $1.37^{\circ} \mathrm{C}$ (Figure 2a), $0.27^{\circ} \mathrm{C}$ (Figure $2 \mathrm{~b}$ ) and $0.27^{\circ} \mathrm{C}$ (Figure $2 \mathrm{c}$ ), and maximum air temperatures reached $34.7^{\circ} \mathrm{C}$ (Figure $3 \mathrm{a}$ ), $26.98^{\circ} \mathrm{C}$ (Figure $3 \mathrm{~b}$ ) and $32.03^{\circ} \mathrm{C}$ (Figure $3 \mathrm{c}$ ), respectively. Interestingly, while minimum air temperatures under the different shading nets were very similar to that of the control (Figure 2), there were differences between the maximum air temperature of the control to those of the shading nets. In general, the highest maximum air temperatures were observed in the control, while the lowest were measured in the Silver 70\% net (Figure 3). For example, on January 19, 2019, which was the coldest day of winter 2018-2019, minimum air temperatures reached $0.27^{\circ} \mathrm{C}, 0.49^{\circ} \mathrm{C}$ and $0.38^{\circ} \mathrm{C}$, while on the same day, maximum air temperatures reached $20.9^{\circ} \mathrm{C}, 17.7^{\circ} \mathrm{C}$ and $16.8^{\circ} \mathrm{C}$ in the control, Silver $50 \%$ and Silver $70 \%$ nets, respectively (Supplemental Figure S2).

\section{Effect of shading nets on maximum quantum yield (Fv/Fm)}

In mid-winter of 2017-2018, Fv/Fm rate was lowest (0.6) in the leaves of trees from the control treatment (Figure 4). Fv/Fm rates were significantly higher under both shading nets. Similar phenomena were observed in mid-winter of 2018-2019 in which the Fv/Fm rate was lowest in the control (0.73), while it was significantly higher under both shading nets. In addition, in mid-winter of 2019-2020, the Fv/Fm rate was also lowest in the control (0.68), while it was significantly higher under both shading nets. In all three years of the experiment, no significant difference was observed between the Fv/Fm rates in the leaves of trees covered with both nets. In early spring of 2018 and 2020, after the shading nets were removed, there were no significant differences in Fv/Fm rates between the control and the shading nets. Only in early spring of 2019, Fv/Fm rates in leaves of trees covered with the Silver 70\% net were significantly higher compared to the control. However, on this date, no significant differences were observed between the Fv/Fm rates of Silver 50\% net to that of the control and the Silver $70 \%$ net.

a

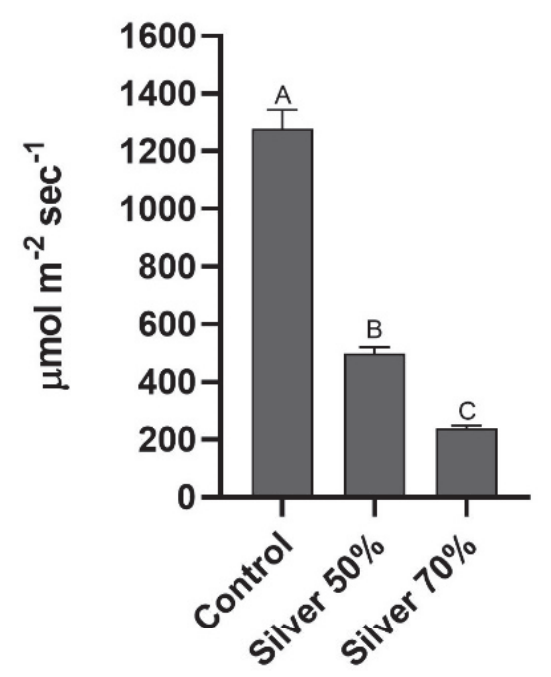

b

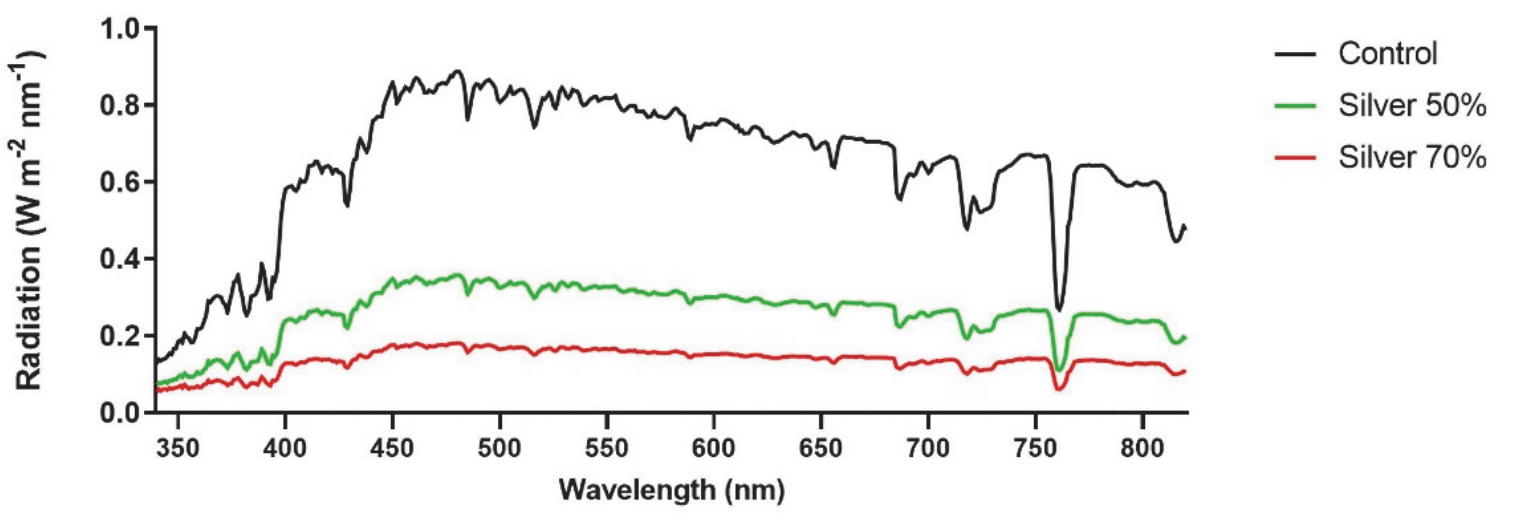

FIGURE 1. Effect of the shading nets on field light measurements. Photosynthetically active radiation (PAR) measurements were taken in February 2018 during the morning in the control and winter-covered plots (a). Values are means \pm S.E. of four replicates $(n=4)$, each comprised of 10 measurements. Columns marked with different letters differ significantly (Tukey-HSD, $P<0.05$ ). Spectra of the total solar light under the different shading nets and the control (sunlight) were measured at noon in November 2020 (b). Values are mean of five replicates for each of the different treatments. 


\section{Effect of shading nets on leaf chlorophyll content}

Leaf chlorophyll concentration was measured for only one year from May 2019 to May 2020 every two months, except during November 2019 (Figure 5). In general, during all months of the measurements, leaf CCI was lowest in trees from the control treatment and highest in trees that were covered during winter with the Silver $70 \%$ net. Specifically, in May 2019 and 2020, leaf CCI rate was significantly higher under the Silver $70 \%$ net compared to the control. On both dates, there was no significant difference between the Silver $50 \%$ net and the control or the Silver $70 \%$ net. In July and September 2019 and in January and March 2020, there was no significant difference between the CCI of the different treatments.

\section{Effect of shading nets on flowering intensity and tree trunk diameter}

Since the trees were juvenile, no apparent flowering was observed during the spring of 2018 (Supplemental Figure S3). In May 2019, flowering intensity was very high in the control trees with no significant difference between the Silver 50\% nets. In this year, flowering intensity in trees covered with the Silver 70\% net was significantly lower than in both other treatments. In the following year, flowering intensity was generally lower. Still, flowering intensity in trees covered with the Silver $70 \%$ net was significantly lower than in the control trees. There was no significant difference between the flowering intensity of trees covered with the Silver $50 \%$ net and the control or the Silver $70 \%$ net-covered trees. Fruit yield was not examined, as the trees were young and did not bear fruits during the duration of this study.

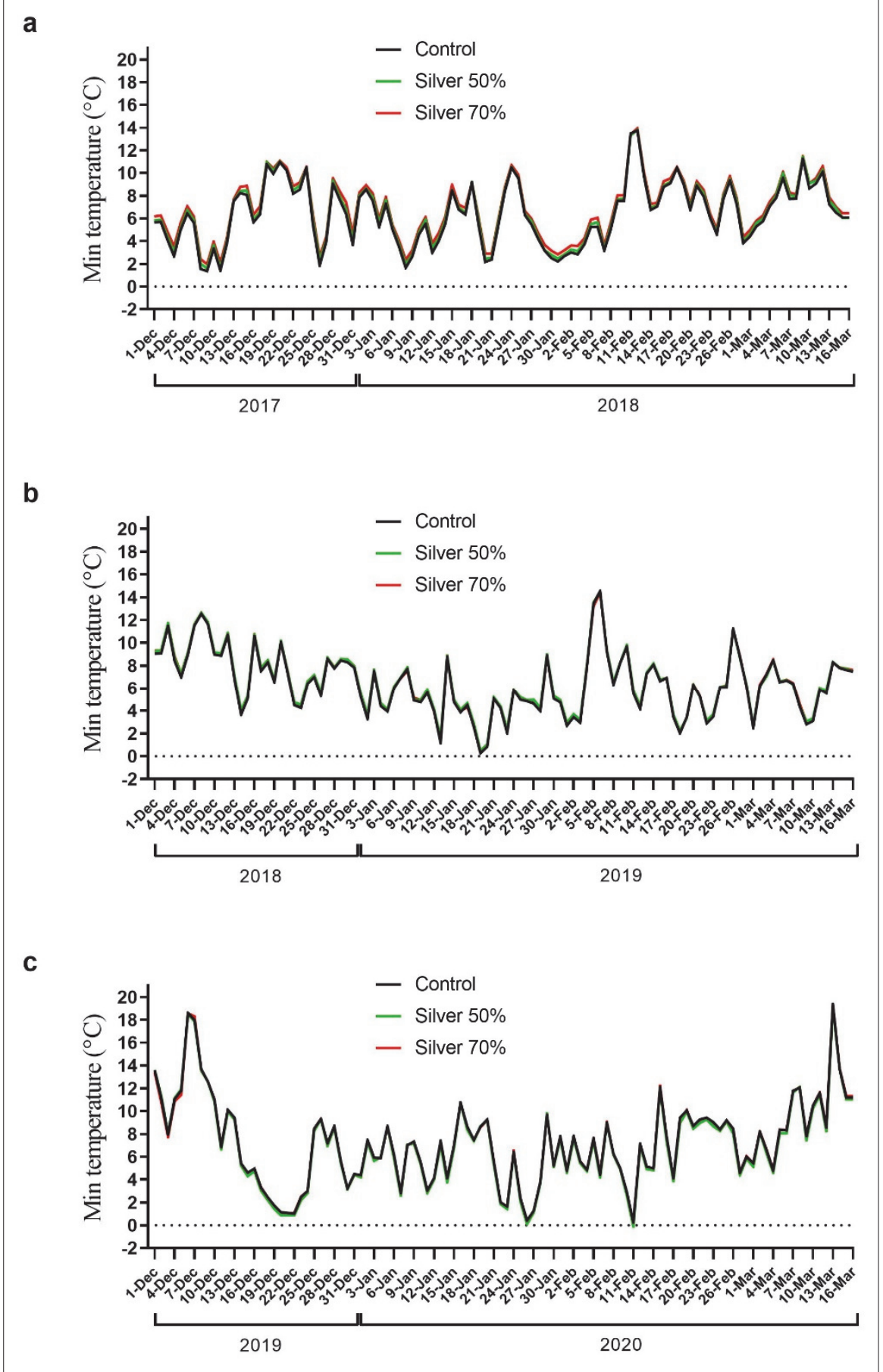

FiguRE 2. Minimum daily air temperatures in the control plots and under the different shading nets during the winters of 20172018 (a), 2018-2019 (b), and 2019-2020 (c). Mean temperature of each treatment is an average of three data loggers. 
Trunk diameter measurements were taken from the end of the first winter of the experiment to the end of the last. In general, at most of the measured time points, trunk diameter of the control trees was lower than that of trees that were covered during winter with either of the shading nets (Figure 6a). In addition, trunk diameter of trees covered with the Silver $70 \%$ was higher compared to trees covered with the Silver 50\% net. In March 2020, which was the final measured time point, trunk diameter of the control trees or trees covered with Silver $50 \%$ and Silver 70\% nets increased by $283 \%, 321 \%$ and $357 \%$, respectively (Figure $6 \mathrm{~b}$ ). The increase in trunk diameter of trees covered with the Silver 70\% net was significantly higher than that of the control trees (by $26.14 \%$ ). There was no significant difference between the trunk diameter of trees covered with the Silver 50\% net and the control or the Silver 70\% net-covered trees.

\section{Discussion}

The purpose of covering the young avocado trees with the different shading nets during winter was to study their protective effect over winter-cold events. No frost damage was observed in the control and the net-covered trees, as minimum air temperature did not decrease below $0^{\circ} \mathrm{C}$ during the three winters of the experiment. Still, a positive effect on tree vegetative growth and other physiological factors was observed in trees covered with either of the shading nets. Of the two nets tested (Silver 50\% and 70\%), only the Silver $70 \%$ net elevated tree trunk growth significantly. This suggests that shading level is an important factor in this effect. Similar or other positive effects of shading nets were also demonstrated in other studies. For example, in South Africa, shading nets were used to increase fruit quality, expected revenue and marketable yield in different avocado cultivars

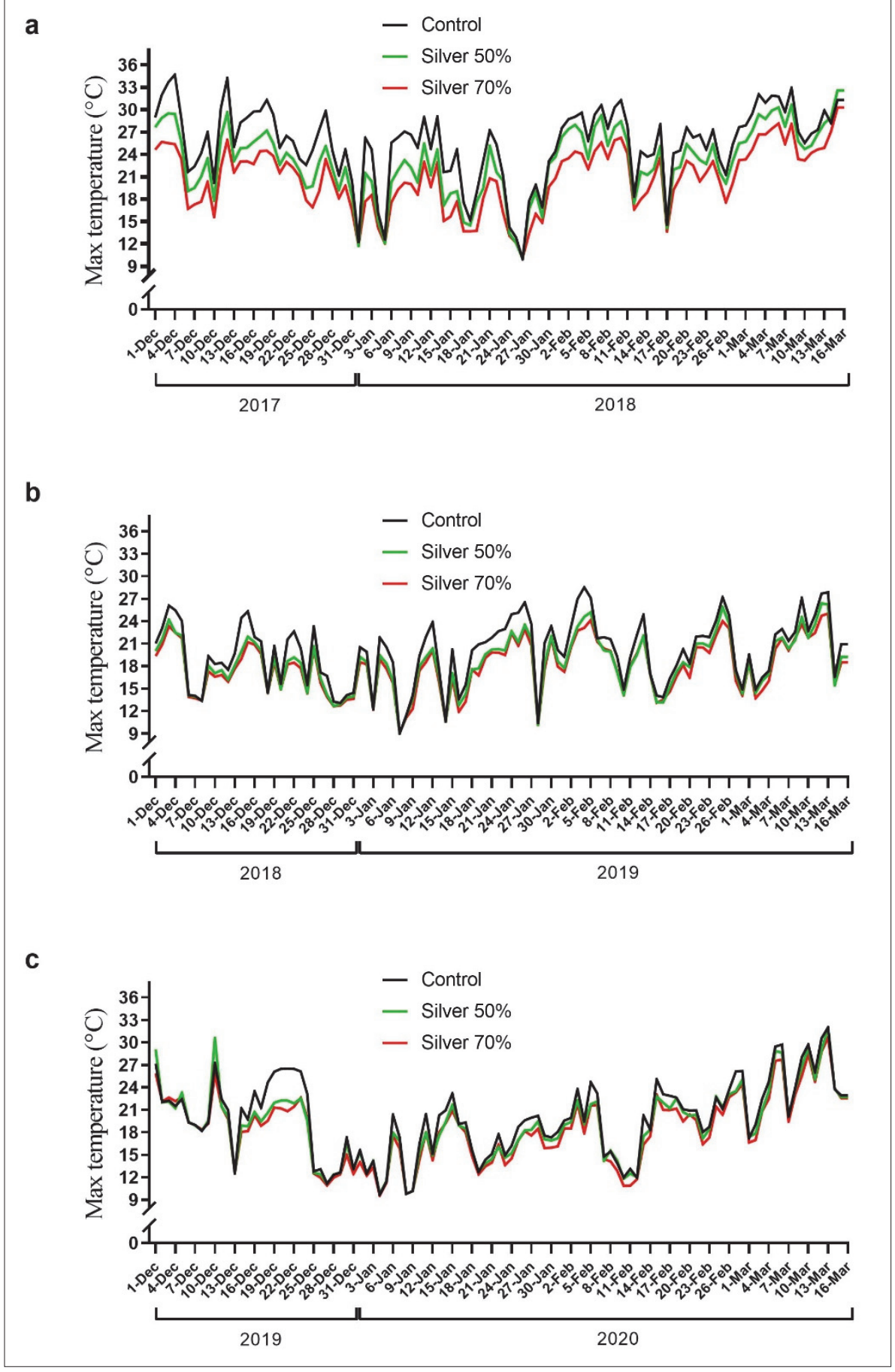

FigURE 3. Maximum daily air temperatures in the control plots and under the different shading nets during the winters of 20172018 (a), 2018-2019 (b), and 2019-2020 (c). Mean temperature of each treatment is an average of three data loggers. 

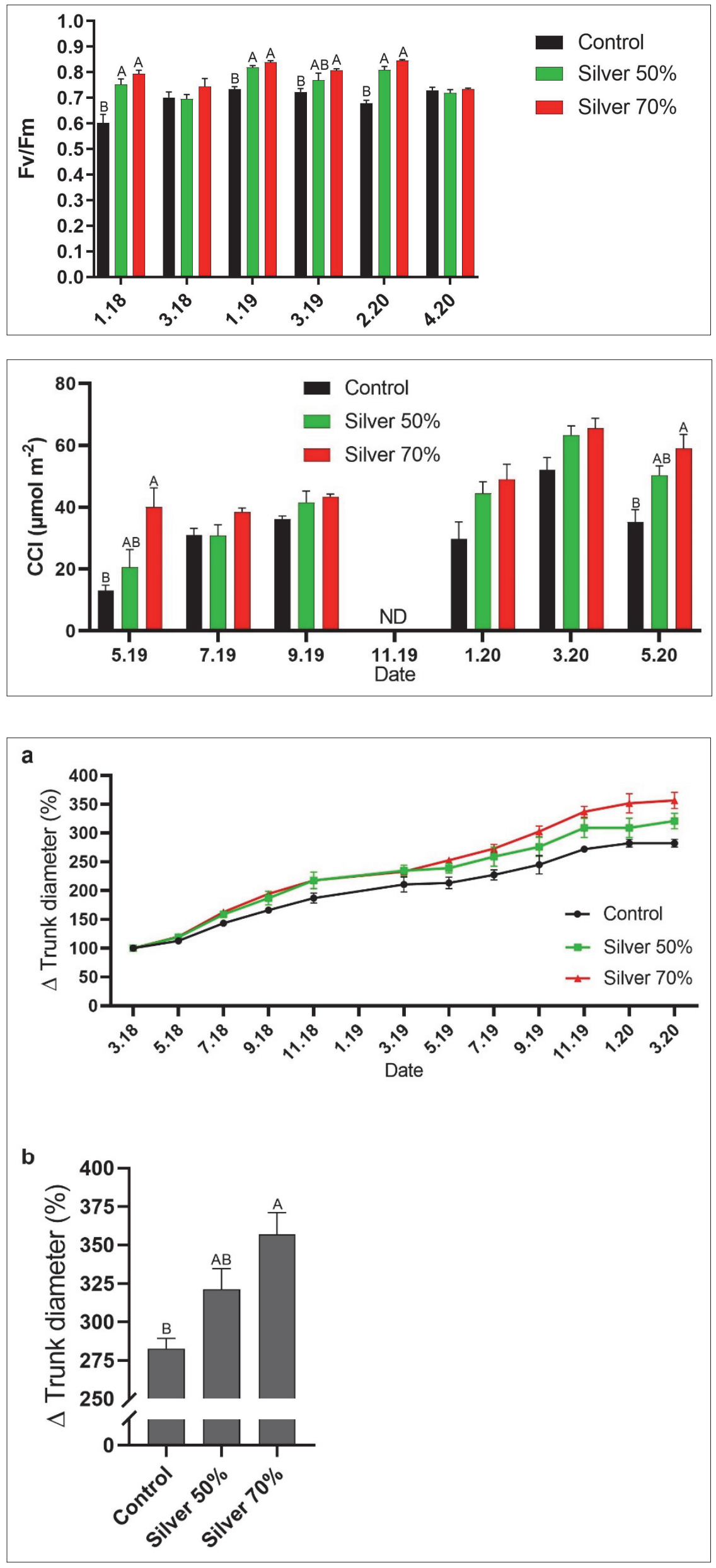

FIGURE 4. Chlorophyll $a$ fluorescence parameter recorded after dark adaptation for the calculation of maximum quantum yield (Fv/Fm). Measurements were taken at two time points in 2018, 2019 and 2020. Values are means \pm S.E. of four replicates $(n=4)$, each comprised of four leaves from each of three different trees. Columns marked with different letters differ significantly (Tukey-HSD, $P<0.05)$; comparisons are made among the same date.

FIGURE 5. Leaf chlorophyll content. Measurements were taken from May 2019 to May 2020 in the control and net-covered trees in 2-month intervals (ND: no data taken). Values are means \pm S.E. of four replicates $(n=4)$, each comprised of four leaves from each of three different trees. Columns marked with differentletters differ significantly (Tukey-HSD, $\quad P<0.05$ ); comparisons are made among the same date.
FiguRE 6. Trunk diameter growth. Measurements were taken in 2-month intervals in the control and netcovered trees (a). The difference in trunk diameter in the period between March 2018 and March 2020 (b). Values are means \pm S.E. of four replicates $(n=4)$, each comprised of three different trees. Columns marked with different letters differ significantly (Tukey-HSD, $P<0.05$ ). 
(Melorose et al., 2015; Tinyane et al., 2018). Still, no sufficient evidence-based data is available regarding the effect of shading nets on cold protection in avocado orchards.

There might be different reasons for the effects of the shading nets on the various parameters examined in this study. Low winter temperatures in combination with high light intensity may result in chill-induced photoinhibition of leaves, leading to a decrease in Fv/Fm values in avocado (Whiley et al., 1999), as well as in other plants (Miura and Furumoto, 2013). As mentioned above, low Fv/Fm values are clear indicators of plant stress in avocado, as well as in other species (Stern, 2015; Weil et al., 2019). The fact that mid-winter $\mathrm{Fv} / \mathrm{Fm}$ values in the control trees reached 0.6, 0.73 and 0.67 in the three consecutive winters of this study (Figure 4), suggests that reversable damage might occur to the photosynthetic system after chilling events followed by high light intensity in the orchard. This putative damage may lead to reduced vegetative tree development and growth. Although there was no apparent elevation in the minimum air temperature under the different shading nets compared to the control (Figures 2-3), PAR intensity was significantly lower (Figure 1). Since high light intensity plays an important role in overall stress during chill events (Wise, 1995), it is possible that chilling stress was lower in the shaded trees, leading to higher Fv/Fm values compared to the control (Figure 4). Previous studies showed that higher Fv/Fm rates were also achieved in citrus trees by covering the plants with the Aluminet 50\% net, which resulted in reduced PAR levels (Jifon and Syvertsen, 2003; Medina et al., 2002).

We also assume that the decrease in maximum air temperature under the shading nets (Figure 3 ) did not have a significant effect on plant stress. Winter maximum air temperatures in northern Israel are usually relatively low. Specifically, air temperatures in the experimental orchard did not reach levels considered to facilitate heat stress in avocado (Lomas, 1992).

It is possible that chilling stress in the control trees caused a reduction in chlorophyll content. Reduction in chlorophyll content may be a strategy to alleviate photoinhibition as it may reduce the light harvesting capacity of the leaf (Kyparissis et al., 1995). For example, leaf chlorophyll content of the evergreen tree Quercus ilex was decreased by $\sim 30 \%$ following cold stress, possibly as an adaptive response against excessive light capture during cold events (Oliveira and Peñuelas, 2000). Also, in Laurus nobilis, chlorophyll content was significantly reduced by $\sim 30 \%$ during winter compared to spring (Meletiou-Christou and Rhizopoulou, 2017). Also, it is possible that in the shaded trees, shading caused an elevation in leaf chlorophyll content to increase photosynthetic effectiveness under lower light intensity. A field study conducted in Florida, showed that shaded avocado leaves had higher chlorophyll content than sun exposed leaves (Reed et al., 2012). Another study showed an increase in chlorophyll content in shaded apple trees compared to trees which were exposed to full sunlight environment (Liu et al., 2019). Thus, the significant higher chlorophyll level in trees covered with the Silver 70\% shading net (Figure 5) may also have had a positive effect on vegetative growth, e.g., trunk diameter, since leaf chlorophyll content represents the physiological status of the plant and its photosynthetic capacity and dry matter production (Croft et al., 2020). For example, in apple trees grown under green-black hail-nets, leaf chlorophyll concentration was increased by up to $46 \%$ followed by an increase in number and length of their one-year vegetative shoots (Solomakhin and Blanke, 2008). Yet, this assumption must be further investigated, since a reduction in chlorophyll content subsequent to chilling stress is not well described in avocado.

That being said, it is possible that the elevated vegetative growth of the shaded trees compared to the control trees was due to the reduction in flowering intensity. Indeed, inflorescence production may lead to reduced vegetative shoots production in avocado (Salazar-García and Lovatt, 2000). Other studies showed that blooming can be manipulated by light spectrum management. For example, the 30\% Red net had a positive effect on flower number in Phalaenopsis plants (Leite et al., 2008). In contrast, covering strawberry transplants with two layers of Blue or Red 30\% ChromatiNet nets significantly delayed flowering (Takeda et al., 2010). It is possible that the reason for the difference between flowering intensity in the tress under the two shading nets, resulted from their light absorbance capacity, as negative correlation was shown between shading level and flowering intensity. Interestingly, the Silver $70 \%$ net that significantly reduced flowering intensity during the two sequential blooming seasons compared to the control (Supplemental Figure S3), had the greatest effect on the increase in trunk diameter (Figure 6). However, the Silver $50 \%$ net that did not significantly reduce flowering intensity during spring of 2019, still elevated trunk diameter, compared to the control. Thus, we assume that the reduction in flower intensity was not the major reason for the elevated vegetative growth of the shaded avocado trees. However, as vegetative growth may effect flowering intensity (Mitra, 2018), it is possible that the elevation in vegetative growth of the shaded avocado trees resulted in a decrease in their flowering intensity.

It is also possible that other shading nets with different light spectrum absorbance would be also effective in mitigating cold stress, as the specific absorbance of the light spectrum of the nets may play an important role in their effect. For instance, a recent study showed that photoselective nets that were deployed year-round over citrus trees had a significant positive effect on physiological performance and plant development, including vegetative growth. Some of the nets showed different effects on the trees while having the same shading level. Thus, it was suggested that the differences in the light spectrum absorbance of the shading nets may be responsible for these differences (Zhou et al., 2018).

\section{Conclusion}

In this study, the effect of covering young 'Reed' avocado trees with different shading nets during winter was examined. Compared to the control trees, higher mid-winter Fv/ Fm values, leaf chlorophyll content and vegetative growth were observed in trees covered with several nets, in particular with the Silver 70\% net. Furthermore, a negative effect on flowering intensity was also observed, again especially in trees covered with the Silver $70 \%$ net. We assume that according to our hypothesis, the positive effect of the shading nets on the physiological parameters may be attributed to the decrease in irradiation levels resulting in a decrease in cold-stress photoinhibition and an increase in chlorophyll content. The results of this study may have an impact on other crops, since the use of shading nets to reduce cold stress could be beneficial in different commercially important tropical and subtropical crops that are sensitive to chilling stress (Miura and Furumoto, 2013). To further elucidate the mechanism of the shading nets on reducing avocado cold stress, additional research under colder conditions should be carried out. Additional physiological variables such as 
photosynthetic rate and stomatal conductivity should be also examined as they were not measured in this study. Also, as the use of shading nets increases water use efficiency in agricultural crops (Mditshwa et al., 2019; Mira-García et al., 2020), this parameter should be also examined in future research, especially in regions with limited water resources. In addition, further research should be conducted to investigate the effects of shading nets on mature, fruit-bearing avocado trees, also during colder winters, where temperature may drop below $0^{\circ} \mathrm{C}$. In conclusion, shading nets may be considered as a possible solution to mitigate cold stress in commercial orchards, reducing grower's losses and enabling geographic distribution and expansion of avocado orchards to colder areas (Charrier et al., 2015).

\section{Acknowledgments}

The authors wish to thank the Israeli Ministry of Agriculture and Rural Development (Grant No. 91-01-0012), Avocado-GAL Corporation and the Israeli Avocado Growers Table for financial support; the Ginegar Plastic Products Ltd. for supplying some of the shading nets, the Ma'ayan Baruch avocado team for all their efforts invested in this study; Ms. Carmit-Sofer-Arad for her assistance in field measurements; and Mr. Michael Noy for his enlightening remarks.

\section{References}

Alcaraz, M.L., Thorp, T.G., and Hormaza, J.I. (2013). Phenological growth stages of avocado (Persea americana) according to the BBCH scale. Sci. Hortic. (Amsterdam) 164, 434-439. https://doi. org/10.1016/j.scienta.2013.09.051.

Baker, N.R. (2008). Chlorophyll fluorescence: A probe of photosynthesis in vivo. Annu. Rev. Plant Biol. 59, 89-113. https:// doi.org/10.1146/annurevarplant.59.032607.092759.

Bar-Noy, Y., Sofer-Arad, C., Perel, M., Cohen, H., Szenes, N., Noy, M., and Rubinovich, L. (2019). Frost protection efficiency evaluation in avocado with a horizontal wind machine. Fruits 74, 124-129. https://doi.org/10.17660/th2019/74.3.4.

Charrier, G., Ngao, J., Saudreau, M., and Améglio, T. (2015). Effects of environmental factors and management practices on microclimate, winter physiology, and frost resistance in trees. Front. Plant Sci. 6, 1-18. https://doi.org/10.3389/fpls.2015.00259.

Croft, H., Chen, J.M., Wang, R., Mo, G., Luo, S., Luo, X., He, L., Gonsamo, A., Arabian, J., Zhang, Y., et al. (2020). The global distribution of leaf chlorophyll content. Remote Sens. Environm. 236. https://doi. org/10.1016/j.rse.2019.111479.

De Melo-Abreu, J.P., Villalobos, F.J., and Mateos, L. (2016). Frost protection. In Principles of Agronomy for Sustainable Agriculture, F.J. Villalobos, and E. Fereres, eds. (Cham, Switzerland: Springer Intl. Publishing), p. 443-457. https://doi.org/10.1007/978-3-31946116-8_29.

Ghaemi, A.A., Rafiee, M.R., and Sepaskhah, A.R. (2009). Treetemperature monitoring for frost protection of orchards in semiarid regions using sprinkler irrigation. Agric. Sci. China 8, 98-107. https://doi.org/10.1016/S1671-2927(09)60014-6.

Hasanuzzaman, M., Nahar, K., and Fujit, M. (2013). Extreme temperature responses, oxidative stress and antioxidant defense in plants. In Abiotic Stress - Plant Responses and Applications in Agriculture (Rijeka, Croatia: InTech), p. 169-205. https://doi. org $/ 10.5772 / 54833$.

Jifon, J.L., and Syvertsen, J.P. (2003). Moderate shade can increase net gas exchange and reduce photoinhibition in citrus leaves. Tree Physiol. 23, 119-127. https://doi.org/10.1093/treephys/23.2.119.
Joshi, N.C., Yadav, D., Ratner, K., Kamara, I., Aviv-Sharon, E., Irihimovitch, V., and Charuvi, D. (2019). Sodium hydrosulfide priming improves the response of photosynthesis to overnight frost and day high light in avocado (Persea americana Mill. cv. 'Hass'). Physiol. Plant. 168(2), 394-405. https://doi.org/10.1111/ppl.13023.

Jouyban, Z., Hasanzade, R., and Sharafi, S. (2013). Chilling stress in plants. Int. J. Agric. Crop Sci. 5, 2961-2968.

Kramer, D.M., Johnson, G., Kiirats, O., and Edwards, G.E. (2004). New fluorescence parameters for the determination of QA redox state and excitation energy fluxes. Photosynth. Res. 79, 209-218. https://doi. org/10.1023/B:PRES.0000015391.99477.0d.

Kyparissis, A., Petropoulou, Y., and Manetas, Y. (1995). Summer survival of leaves in a soft-leaved shrub (Phlomis fruticosa L., Labiatae) under Mediterranean field conditions: Avoidance of photoinhibitory damage through decreased chlorophyll contents. J. Exp. Bot. 46, 1825-1831. https://doi.org/10.1093/jxb/46.12.1825.

Leite, C.A., Ito, R.M., Lee, G.T.S., Ganelevin, R., and Fagnani, M.A. (2008). Light spectrum management using colored nets to control the growth and blooming of Phalaenopsis. Acta Hortic. 770, 177184. https://doi.org/10.17660/ActaHortic.2008.770.20.

Liu, Y.J., Zhang, W., Wang, Z.B., Ma, L., Guo, Y.P., Ren, X.L., and Mei, L.X. (2019). Influence of shading on photosynthesis and antioxidative activities of enzymes in apple trees. Photosynthetica 57, 857-865. https://doi.org/10.32615/ps.2019.081.

Lomas, J. (1992). Analysis of the effect of heat stress during flowering on the yield of avocado under Mediterranean climatic conditions. Agric. For. Meteorol. 59, 207-216. https://doi.org/10.1016/01681923(92)90093-J.

Manja, K., and Aoun, M. (2019). The use of nets for tree fruit crops and their impact on the production: A review. Sci. Hortic. (Amsterdam) 246, 110-122. https://doi.org/10.1016/j.scienta.2018.10.050.

Mditshwa, A., Magwaza, L.S., and Tesfay, S.Z. (2019). Shade netting on subtropical fruit: Effect on environmental conditions, tree physiology and fruit quality. Sci. Hortic. (Amsterdam) 256, 108556. https://doi.org/10.1016/j.scienta.2019.108556.

Medina, C.L., Souza, R.P., Machado, E.C., Ribeiro, R.V., and Silva, J.A.B. (2002). Photosynthetic response of citrus grown under reflective aluminized polypropylene shading nets. Sci. Hortic. (Amsterdam) 96, 115-125. https://doi.org/10.1016/S0304-4238(02)00085-7.

Meletiou-Christou, M.S., and Rhizopoulou, S. (2017). Leaf functional traits of four evergreen species growing in Mediterranean environmental conditions. Acta Physiol. Plant. 39, 1-13. https://doi. org/10.1007/s11738-016-2330-4.

Melorose, J., Perroy, R., and Careas, S. (2015). Growing avocados under shade netting. Statew. Agric. L. Use Baseline 2015 1, 76-79.

Migliore, G., Farina, V., Tinervia, S., Matranga, G., and Schifani, G. (2017). Consumer interest towards tropical fruit: Factors affecting avocado fruit consumption in Italy. Agric. Food Econ. 5, 24. https:// doi.org/10.1186/s40100-017-0095-8.

Mira-García, A.B., Conejero, W., Vera, J., and Ruiz-Sánchez, M.C. (2020). Leaf water relations in lime trees grown under shade netting and open-air. Plants 9(4), 510. https://doi.org/10.3390/plants9040510.

Mitra, S.K. (2018). Paclobutrazol in flowering of some tropical and subtropical fruits. Acta Hortic. 1206, 27-34. https://doi. org/10.17660/ActaHortic.2018.1206.4.

Miura, K., and Furumoto, T. (2013). Cold signaling and cold response in plants. Int. J. Molec. Sci. 14, 5312-5337. https://doi.org/10.3390/ ijms14035312.

Oliveira, G., and Peñuelas, J. (2000). Comparative photochemical and phenomorphological responses to winter stress of an evergreen (Quercus ilex L.) and a semi-deciduous (Cistus albidus L.) 
Mediterranean woody species. Acta Oecologica 21, 97-107. https:// doi.org/10.1016/S1146-609X(00)00121-1.

Reed, S., Schnell, R., Moore, J.M., and Dunn, C. (2012). Chlorophyll $a+b$ content and chlorophyll fluorescence in Avocado. J. Agric. Sci. 4, 29-36. https://doi.org/10.5539/jas.v4n4p29.

Ribeiro, A.C., De Melo-Abreu, J.P., and Snyder, R.L. (2006) Apple orchard frost protection with wind machine operation. Agric. For. Meteorol. 141, 71-81. https://doi.org/10.1016/j. agrformet.2006.08.019.

Salazar-García, S., and Lovatt, C.J. (2000). Use of $\mathrm{GA}_{3}$ to manipulate flowering and yield of "Hass" avocado. J. Am. Soc. Hortic. Sci. 125, 25-30. https://doi.org/10.21273/JASHS.125.1.25.

Schaffer, B., Gil, P., Mickelbart, M., and Whiley, A. (2013). Ecophysiology of avocado. In The Avocado: Botany, Production and Uses, B. Schaffer, B. Wolstenholme, and A. Whiley, eds. (Wallingford, U.K.: CABI) p. 168-199. https://doi.org/10.1079/9781845937010.0168.

Schreiber, U., Schliwa, U., and Bilger, W. (1986). Continuous recording of photochemical and non-photochemical chlorophyll fluorescence quenching with a new type of modulation fluorometer. Photosynth. Res. 10, 51-62. https://doi.org/10.1007/BF00024185.

Shahak, Y., Gussakovsky, E.E., Gal, E., and Ganelevin, R. (2004). ColorNets: Crop protection and light-quality manipulation in one technology. Acta Hortic. 659, 143-151. https://doi.org/10.17660/ ActaHortic.2004.659.17.

Shahak, Y., Ratner, K., Giller, Y.E., Zur, N., Or, E., Gussakovsky, E.E., Stern, R., Sarig, P., Raban, E., Harcavi, E., et al. (2008). Improving solar energy utilization, productivity and fruit quality in orchards and vineyards by photoselective netting. Acta Hortic. 772, 65-72. https://doi.org/10.17660/ActaHortic.2008.772.7.

Silva, T.A., and Ledesma, N. (2014). Avocado history, biodiversity and production. In Sustainable Horticultural Systems, D. Nandawani, ed. (Switzerland: Springer Intl. Publishing), p. 157-205. https://doi. org/10.1007/978-3-319-06904-3_8.

Solomakhin, A., and Blanke, M.M. (2008). Coloured hailnets alter light transmission, spectra and phytochrome, as well as vegetative growth, leaf chlorophyll and photosynthesis and reduce flower induction of apple. Plant Growth Regul. 56, 211-218. https://doi. org/10.1007/s10725-008-9302-7.

Stern, R.A. (2015). The photosynthesis inhibitor metamitron is a highly effective thinner for 'Golden Delicious' apple in a warm climate. Fruits 70(3), 127-134. https://doi.org/10.1051/fruits/2015007.

Takeda, F., Glenn, D.M., Callahan, A., Slovin, J., and Stutte, G.W. (2010). Delaying flowering in short-day strawberry transplants with photoselective nets. Int. J. Fruit Sci. 10, 134-142. https://doi.org/10. $1080 / 15538362.2010 .492331$.

Teitel, M., Peiper, U.M., and Zvieli, Y. (1996). Shading screens for frost protection. Agric. For. Meteorol. 81, 273-286. https://doi. org/10.1016/0168-1923(95)02321-6.

Tinyane, P.P., Soundy, P., and Sivakumar, D. (2018). Growing 'Hass' avocado fruit under different coloured shade netting improves the marketable yield and affects fruit ripening. Sci. Hortic. (Amsterdam) 230, 43-49. https://doi.org/10.1016/j.scienta.2017.11.020.

Weil, A., Sofer-Arad, C., Bar-Noy, Y., Liran, O., and Rubinovich, L. (2019). Comparative study of leaf antioxidant activity as a possible mechanism for frost tolerance in 'Hass' and 'Ettinger' avocado cultivars. J. Agric. Sci. 157, 342-349. https://doi.org/10.1017/ S0021859619000662.

Whiley, A.W., Searle, C., Schaffer, B., and Wolstenholme, B.N. (1999). Cool orchard temperatures or growing trees in containers can inhibit leaf gas exchange of avocado and mango. J. Am. Soc. Hortic. Sci. 124, 46-51. https://doi.org/10.21273/JASHS.124.1.46.
Wise, R.R. (1995). Chilling-enhanced photooxidation: The production, action and study of reactive oxygen species produced during chilling in the light. Photosynth. Res. 45, 79-97. https://doi. org/10.1007/BF00032579.

Zait, Y., Elingold, I., Londener, A., Gal, E., Or, G., and Galpaz, N. (2020). Banana frost protection by thermal nets. Acta Hortic. 1272, 21-26. https://doi.org/10.17660/ActaHortic.2020.1272.3.

Zaro, G.C., Caramori, P.H., De Oliveira, C.M.G., Nagashima, G.T., Rosisca, J.R., and Prete, C.E.C. (2019). Assessment of cold stress in avocado cultivars based on visual, physiological and biochemical criteria. Australian J. Crop Sci. 13, 881-888. https://doi.org/10.21475/ ajcs.19.13.06.p1593.

Zhang, X., Lu, C., and Guan, Z. (2012). Weakened cyclones, intensified anticyclones and recent extreme cold winter weather events in Eurasia. Environm. Res. Lett. 7(4). https://doi.org/10.1088/17489326/7/4/044044.

Zhou, K., Jerszurki, D., Sadka, A., Shlizerman, L., Rachmilevitch, S., and Ephrath, J. (2018). Effects of photoselective netting on root growth and development of young grafted orange trees under semiarid climate. Sci. Hortic. (Amsterdam) 238, 272-280. https://doi. org/10.1016/j.scienta.2018.04.054.

Ziv, D., Zviran, T., Zezak, O., Samach, A., and Irihimovitch, V. (2014). Expression profiling of FLOWERING LOCUS T-like gene in alternate bearing "Hass" avocado trees suggests a role for PaFT in avocado flower induction. PLoS ONE 9, 1-14. https://doi.org/10.1371/ journal.pone.0110613.

Received: Apr. 19, 2021

Accepted: Jun. 28, 2021

Addresses of authors:

Simon Chernoivanov ${ }^{1}$, Itamar Neuberger ${ }^{1}$, Shay Levy ${ }^{1}$,

Nitzan Szenes ${ }^{2}$ and Lior Rubinovich ${ }^{1, *}$

1 Northern R\&D, MIGAL - Galilee Research Institute,

P.O. Box 831, Kiryat Shmona, Israel

${ }^{2}$ Agricultural Extension Service, Israel Ministry of

Agriculture \& Rural Development, Beit Dagan 50250, Israel

* Corresponding author; E-mail: liorr@migal.org.il 


\section{SUPPLEMENTAL INFORMATION}

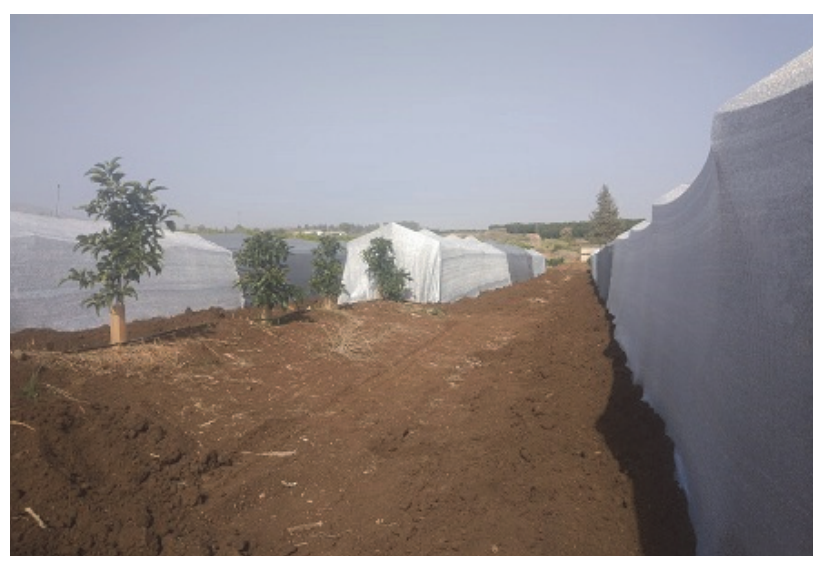

SUPPLEMENTAL INFORMATION - FiguRE S1. The experimental avocado orchard. Picture was taken on November 28, 2017 , soon after the trees were covered by the shading nets for the first time.

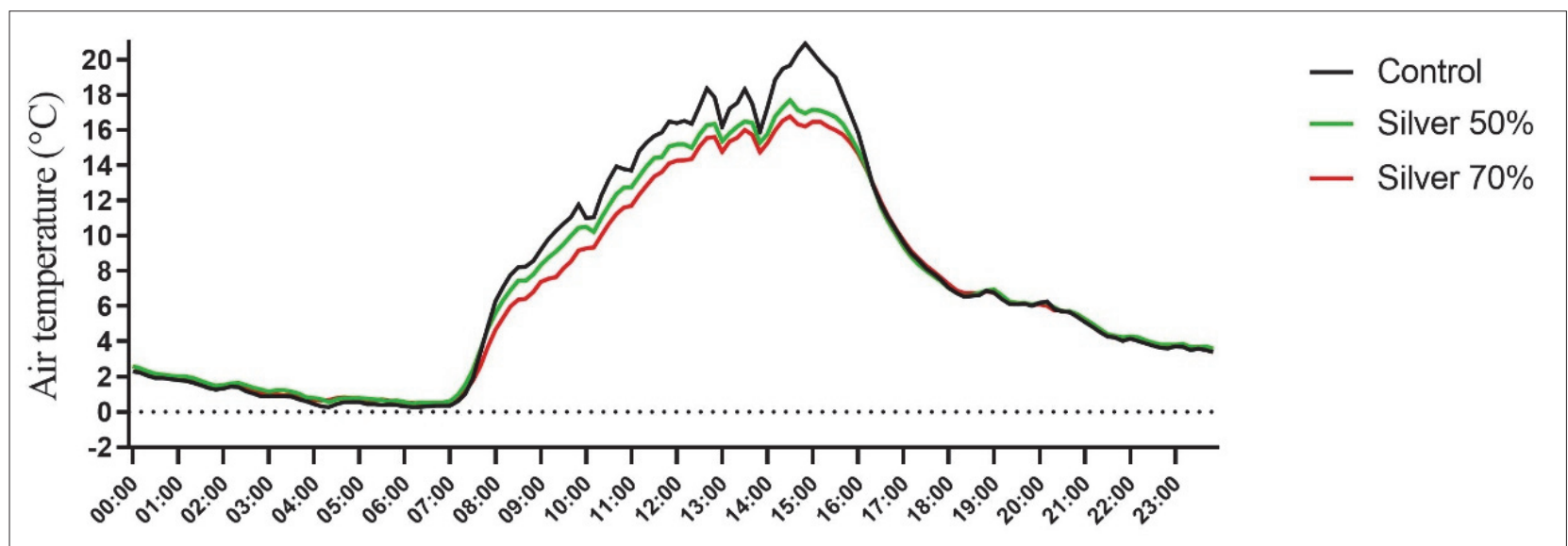

SUPPLEMENTAL INFORMATION - FiguRE S2. Daily air temperatures in the control plots and under the different shading nets on January 19, 2019. Mean temperature of each treatment is an average of three data loggers.

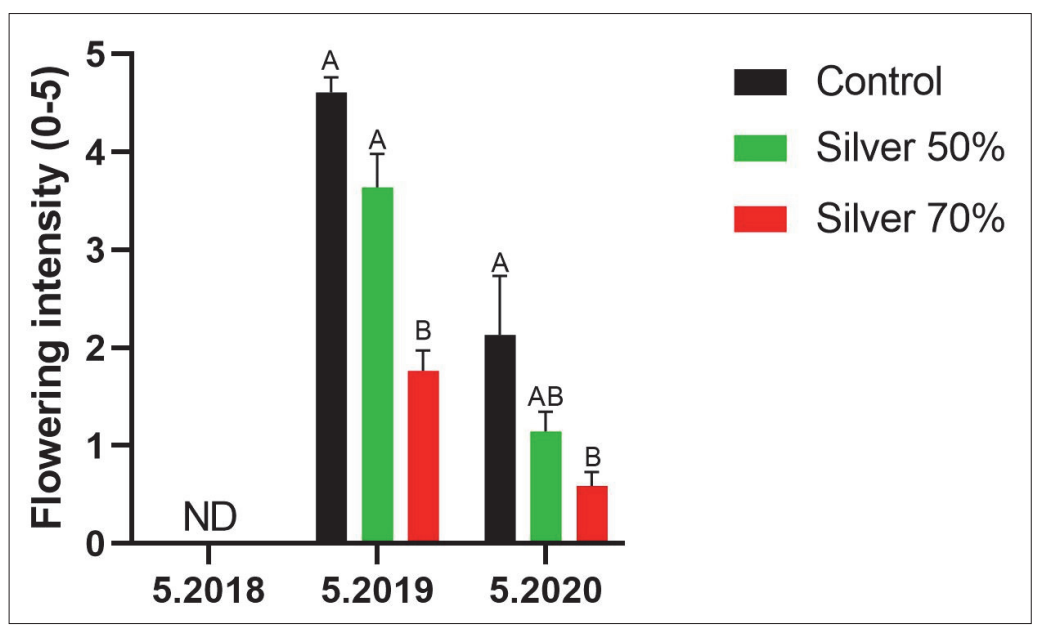

SUPPLEMENTAL INFORMATION - FIGURE S3. Flowering intensity was assessed and scored in May 2019 and May 2020 on a scale of $0-5$, with 0 representing no apparent flowering and 5 maximum bloom. Values are means \pm S.E. of four replicates $(n=4)$, each comprised of three different trees. Columns marked with different letters differ significantly (Tukey-HSD, $P<0.05$ ); comparisons are made among the same date. 